\title{
Effect of group hope therapy on self-efficacy of adolescents with type 1 diabetes
}

\author{
Nasim Nikbakhtan Esfahani' (i), Sedigheh Talakoub ${ }^{(1)}$, \\ Soheila Jafari-Mianaei1,2* (1), Neda Mostofizadeh ${ }^{3}$
}

\begin{abstract}
SUMMARY
OBJECTIVE: This study aims to determine the effect of group hope therapy on the self-efficacy of adolescents with type 1 diabetes. METHODS: This randomized clinical trial was conducted on 45 adolescent patients with type 1 diabetes in Iran. The subjects were randomly assigned into the intervention and control groups. The intervention group received eight 90-min sessions of group hope therapy using Snyder's method.

RESULTS: The mean score of self-efficacies in the intervention group was significantly higher than the control group $(p<0.05)$. CONCLUSION: The results of the study suggested that group hope therapy had a significant impact on self-efficacy of adolescents with type 1 diabetes but had no effect on academic self-efficacy and self-efficacy in blood glucose management.

KEYWORDS: Hope. Diabetes mellitus. Self efficacy. Iran. Adolescent.
\end{abstract}

\section{INTRODUCTION}

Self-efficacy refers to an individual's belief in his or her capacity to execute behaviors necessary to produce specific performance attainments. Factors that influence diabetes control include the association between self-efficacy and self-care behaviors. When diabetes control is achieved, complications decline and hence quality of life increases ${ }^{1}$. Children and adolescents with type 1 diabetes (T1D) do not have an appropriate emotional response and experience a low-level mental well-being and self-efficacy because of problems such as diet, limited activity, invasive monitoring of blood sugar, daily insulin injections, chronic physical complications, and hospitalization imposed on them by the disease. All these conditions lead adolescents to low quality of life ${ }^{2}$. Hope therapy is a healthcare program designed based on Snyder's theory to increase hopeful thinking and strengthen activities related to goal achievement that is derived from cognitive-behavioral therapies, solution-based treatments, and fictional and narrative treatment ${ }^{3}$. In hope therapy, participants are taught how to set their own goals, create strategies to achieve those goals, develop the motivation for implementing them, and maintain them along the way ${ }^{4}$. Given the fact that group training is effective in increasing patients' motivation to follow treatment recommendations, this treatment is done collectively as group therapy. Although some studies have been conducted to investigate the relationship between self-efficacy, quality of life, and self-care, only few studies have examined the increase of self-efficacy in diabetic adolescents. Accordingly, no study has been found concerning the effect of group hope therapy on self-efficacy in diabetic adolescents. Therefore, the present study was conducted to determine the effect of training group hope therapy on the self-efficacy of the adolescents with T1D.

\footnotetext{
'Isfahan University of Medical Sciences, School of Nursing and Midwifery, Department of Pediatric and Neonatal Nursing - Isfahan, Iran.

${ }^{2}$ Nursing and Midwifery Care Research Center - Isfahan, Iran.

${ }^{3}$ Isfahan University of Medical Science, Metabolic liver Disease Research Center - Isfahan, Iran.

*Corresponding author: m_jafari@nm.mui.ac.ir

Conflicts of interest: the authors declare there is no conflicts of interest. Funding: none.

Received on August 14, 2021. Accepted on September 19, 2021.
} 


\section{METHODS}

\section{Sample and study design}

The present study is a randomized controlled trial that includes the pre-test, post-test, and 2-month follow-up stages and was conducted from August to November 2019 in Iran. The study population consisted of all adolescents with T1D who had referred to Isfahan Endocrine and Metabolism Research Center (IEMRC). Using convenience sampling method, 46 patients were selected and randomly allocated to the intervention and control groups (23 in each group). Inclusion criteria were T1D, passage of at least 6 months from diagnosis, 13-19 years old, no participation in other psychotherapy programs, no other physical illness, no mental illness or crisis, and no severe mental stress including death of a parent or sibling, parental divorce, and severe accident in the past 6 months. The samples were selected from files of the patients with T1D in IEMRC. Participants and their parents signed a consent form. The members of the intervention group were randomly divided into two groups, each consisting of 11 and 12 to participate in hope therapy sessions, which were held in eight 90-min sessions twice a week. The contents of the classes were based on 2000 Snyder's hope therapy program (Table 1). No intervention was performed for the control group, and they received only routine diabetes selfcare training provided by the center itself.

Self-efficacy questionnaires were completed three times, that is, before the intervention, immediately after completing the eight treatment sessions of the intervention group, and 2 months later by all participants of the study.

\section{Measures}

The demographic characteristics questionnaire and the Self-Efficacy Questionnaire for Children (SEQ_C), which has been developed by Muris in 2001 based on the Bandura Self-Efficacy Questionnaire, consist of 23 questions in three categories: social, educational, and emotional self-efficacy. The Cronbach's alpha coefficient is 0.80 and the reliability is $0.70^{5}$. The Diabetes Management Self-Efficacy Scale (DMSES) was developed in 1999 by Van der Bijl et al. and consists of 19 questions in four categories. The Cronbach's alpha coefficient for this instrument is 0.92 and its reliability is $0.89^{6}$.

\section{Statistical analysis}

Independent $t$-tests (quantitative variables), Mann-Whitney U test (ranked qualitative variables), and chi-square or Fisher's exact test (nominal qualitative variables) were used to compare the demographic characteristics between the two groups.

\section{Ethical considerations}

The research ethics committee of Isfahan University of Medical Sciences (IR.MUI.RESEARCH.REC.1398.365) approved the study. This study was registered at the Iranian Registry of Clinical Trials (IRCT20190813044520N1).

\section{RESULTS}

The mean age of the participants was $16.36 \pm 0.45$ years and the duration of illness was $6.38 \pm 0.86$ years. Regarding demographic variables, such as age, gender, diabetes history, educational level, and parental characteristics, there was no significant difference between the two groups ( $p>0.05)$. The self-efficacy of the intervention group was higher than that of the control group after the intervention, and according to the experiment conducted in the next two months, an increase in self-efficacy was persistent in the intervention group (Table 2). Repeated-measures analysis of variance (ANOVA) showed that group hope therapy has no effect on the component of educational self-efficacy but has increased self-efficacy in the social and emotional domains of the adolescents (Table 3). Also, there has been no effect on the field of blood sugar measurement but has increased self-efficacy in the domains of diet, physical activity, and drug administration of the adolescents (Table 4).

Table 1. General outline of hope therapy program for diabetic patients.

\begin{tabular}{c|c} 
Sessions & Content \\
\hline 1 & $\begin{array}{c}\text { Initial familiarization with the participants } \\
\text { The importance of having hope in life, its role } \\
\text { in the problem-solving process, familiarizing } \\
\text { the subjects with the features and effects of } \\
\text { hope in life }\end{array}$ \\
\hline 3 & $\begin{array}{c}\text { Listening to the life story of each member of } \\
\text { the group }\end{array}$ \\
\hline 4 & $\begin{array}{c}\text { Expressing the strengths of each member } \\
\text { from the perspective of other group } \\
\text { members }\end{array}$ \\
\hline 5 & $\begin{array}{c}\text { Introducing and writing a list of current } \\
\text { events and important aspects of life by each } \\
\text { member }\end{array}$ \\
\hline 7 & $\begin{array}{c}\text { Expressing the characteristics of goal setting } \\
\text { based on Snyder's theory in optimistic } \\
\text { subjects }\end{array}$ \\
\hline 8 & $\begin{array}{c}\text { Choosing the right solutions by each person } \\
\text { to achieve the preset goals and teaching how } \\
\text { to turn the pathways into small steps }\end{array}$ \\
\hline $\begin{array}{c}\text { An overview of the conducted interventions } \\
\text { and providing solutions to create and } \\
\text { maintain motivation }\end{array}$ \\
\hline
\end{tabular}


Table 2. Comparison of the mean total score of children and adolescents' self-efficacy and diabetes management self-efficacy between the two groups at three times.

\begin{tabular}{|c|c|c|c|c|c|c|c|c|c|c|c|}
\hline \multirow[t]{2}{*}{ Component } & \multirow[t]{2}{*}{ Group } & \multirow[t]{2}{*}{$\mathrm{N}^{\circ}$} & \multicolumn{2}{|c|}{$\begin{array}{c}\text { Before } \\
\text { the } \\
\text { intervention }\end{array}$} & \multicolumn{2}{|c|}{$\begin{array}{l}\text { Immediately } \\
\text { after the } \\
\text { intervention }\end{array}$} & \multicolumn{2}{|c|}{$\begin{array}{l}\text { Two months } \\
\text { after the } \\
\text { intervention }\end{array}$} & \multicolumn{3}{|c|}{$\begin{array}{c}\text { Repeated-measures } \\
\text { ANOVA }\end{array}$} \\
\hline & & & $\mathrm{M}$ & SD & M & SD & $\mathrm{M}$ & SD & $F$ & df & $p$ \\
\hline \multirow{2}{*}{$\begin{array}{l}\text { Child and } \\
\text { teenager } \\
\text { self-efficacy }\end{array}$} & Intervention & 23 & 80.96 & 10.37 & 86.52 & 11.63 & 89.95 & 13.17 & 7.34 & 20,2 & 0.004 \\
\hline & Control & 22 & 81.41 & 11.10 & 80.14 & 10.75 & 79.38 & 12.55 & 0.75 & 19,2 & 0.480 \\
\hline \multirow{2}{*}{$\begin{array}{l}\text { Diabetes } \\
\text { management } \\
\text { self-efficacy }\end{array}$} & Intervention & 23 & 131.25 & 31.32 & 153.26 & 35.01 & 154.73 & 36.79 & 8.76 & 20,2 & 0.002 \\
\hline & Control & 22 & 129.86 & 34.29 & 129.91 & 34.49 & 128.81 & 37.67 & 0.02 & 19,2 & 0.980 \\
\hline
\end{tabular}

ANOVA: analysis of variance; $\mathrm{df}$ : degrees of freedom; SD: standard deviation.

Table 3. Comparison of the mean total score of children and adolescents' self-efficacy and its domains between the two groups at three times.

\begin{tabular}{|c|c|c|c|c|c|c|c|c|c|c|}
\hline \multirow{2}{*}{$\begin{array}{l}\text { Domains of } \\
\text { child and } \\
\text { teenager self- } \\
\text { efficacy }\end{array}$} & \multirow[t]{2}{*}{ Group } & \multicolumn{2}{|c|}{$\begin{array}{l}\text { Before the } \\
\text { intervention }\end{array}$} & \multicolumn{2}{|c|}{$\begin{array}{l}\text { Immediately } \\
\text { after the } \\
\text { intervention }\end{array}$} & \multicolumn{2}{|c|}{$\begin{array}{l}\text { Two months } \\
\text { after the } \\
\text { intervention }\end{array}$} & \multicolumn{3}{|c|}{$\begin{array}{c}\text { Repeated-measures } \\
\text { ANOVA }\end{array}$} \\
\hline & & M & SD & $\mathrm{M}$ & SD & $\mathrm{M}$ & SD & $F$ & df & $p$ \\
\hline \multirow{2}{*}{ Total score } & Intervention & 80.96 & 10.37 & 86.52 & 11.63 & 89.95 & 13.17 & 7.34 & 20,2 & 0.004 \\
\hline & Control & 81.41 & 11.10 & 80.14 & 10.75 & 79.38 & 12.55 & 0.75 & 19,2 & 0.480 \\
\hline \multirow{2}{*}{ Social } & Intervention & 28.96 & 4.32 & 33.22 & 4.45 & 34.59 & 4.95 & 29.81 & 20,2 & $<0.001$ \\
\hline & Control & 29.73 & 4.93 & 29.54 & 4.90 & 29.29 & 4.99 & 0.14 & 19,2 & 0.870 \\
\hline \multirow{2}{*}{ Educational } & Intervention & 30.43 & 4.76 & 30.09 & 4.89 & 30.41 & 5.69 & 0.25 & 20,2 & 0.780 \\
\hline & Control & 31.32 & 4.72 & 30.82 & 4.33 & 30.29 & 4.73 & 0.91 & 19,2 & 0.420 \\
\hline \multirow{2}{*}{ Emotional } & Intervention & 21.57 & 4.74 & 23.22 & 4.45 & 24.95 & 5.08 & 5.18 & 20,2 & 0.010 \\
\hline & Control & 20.36 & 5.21 & 19.77 & 4.92 & 19.81 & 5.41 & 0.54 & 19,2 & 0.590 \\
\hline
\end{tabular}

ANOVA: analysis of variance; $\mathrm{df}$ : degrees of freedom; SD: standard deviation.

Table 4. Comparison of the mean total score of diabetes management self-efficacy and its domains between the two groups at three times.

\begin{tabular}{|c|c|c|c|c|c|c|c|c|c|c|}
\hline \multirow{2}{*}{$\begin{array}{l}\text { Domains of } \\
\text { child and } \\
\text { teenager self- } \\
\text { efficacy }\end{array}$} & \multirow[t]{2}{*}{ Group } & \multicolumn{2}{|c|}{$\begin{array}{l}\text { Before the } \\
\text { intervention }\end{array}$} & \multicolumn{2}{|c|}{$\begin{array}{l}\text { Immediately } \\
\text { after the } \\
\text { intervention }\end{array}$} & \multicolumn{2}{|c|}{$\begin{array}{l}\text { Two months } \\
\text { after the } \\
\text { intervention }\end{array}$} & \multicolumn{3}{|c|}{$\begin{array}{c}\text { Repeated--measures } \\
\text { ANOVA }\end{array}$} \\
\hline & & M & SD & $\mathrm{M}$ & SD & $\mathrm{M}$ & SD & $F$ & df & $P$ \\
\hline \multirow{2}{*}{ Total score } & Intervention & 131.25 & 31.32 & 153.26 & 35.01 & 154.73 & 36.79 & 8.76 & 20,2 & 0.002 \\
\hline & Control & 129.86 & 34.29 & 129.91 & 34.49 & 128.81 & 37.67 & 0.02 & 19,2 & 0.980 \\
\hline \multirow{2}{*}{ Diet } & Intervention & 44.96 & 17.31 & 57.52 & 19.01 & 58.86 & 21.75 & 9.52 & 20,2 & 0.001 \\
\hline & Control & 44.82 & 19.47 & 45 & 19.57 & 45.48 & 19.69 & 0.17 & 19,2 & 0.840 \\
\hline \multirow{2}{*}{ Glucometry } & Intervention & 31.91 & 7.29 & 32.74 & 8.91 & 32.50 & 8.42 & 0.22 & 20,2 & 0.800 \\
\hline & Control & 31.32 & 6.07 & 30.86 & 6.62 & 31 & 7.25 & 0.21 & 19,2 & 0.810 \\
\hline \multirow{2}{*}{ Physical activity } & Intervention & 30.38 & 6.76 & 34.52 & 7.34 & 34.14 & 7.29 & 6.08 & 20,2 & 0.009 \\
\hline & Control & 29.64 & 9.58 & 29.59 & 8.35 & 28.67 & 8.52 & 0.16 & 19,2 & 0.850 \\
\hline \multirow{2}{*}{$\begin{array}{l}\text { Drug } \\
\text { administration }\end{array}$} & Intervention & 24 & 4.48 & 28.48 & 4.57 & 29.26 & 2.22 & 20.79 & 20,2 & $<0.001$ \\
\hline & Control & 24.09 & 6.29 & 24.45 & 6.41 & 23.67 & 7.95 & 0.49 & 19,2 & 0.620 \\
\hline
\end{tabular}

ANOVA: analysis of variance; $\mathrm{df}$ : degrees of freedom; SD: standard deviation. 


\section{DISCUSSION}

This study investigated the effect of group hope therapy on self-efficacy of the adolescents with T1D. The results showed that group hope therapy based on Snyder's theory has a significant effect on self-efficacy of the adolescents with T1D. This finding was consistent with the results of previous studies ${ }^{7-11}$. For example, the study conducted by Karimi et al. revealed that hope therapy had $28 \%$ increase in self-efficacy of patients with diabetes $^{12}$. During hope therapy and after setting a goal, people look for ways to achieve the goal by assessing obstacles and barriers and thinking about ways to overcome them. This helps individuals find their abilities and motivations, in which indirectly makes them confident and increases their self-efficacy ${ }^{11}$. However, the results of the present study are not in line with the study conducted by Moayed et al. Although hope therapy training in their study increased self-efficacy, its effect was not significant ${ }^{13}$. This difference can be attributed to factors such as the effect of personality traits of each sample on the results, gender of the samples, and different follow-up methods.

Another finding of the present study was that despite the increase in self-efficacy of measuring blood sugar in the intervention group, the effect of hope therapy was not significant, which is consistent with the results obtained by Datye et al. ${ }^{14}$ They found that psychological interventions had no or a moderate effect on self-care behaviors and blood glucose measurements in adolescents with diabetes. Furthermore, Dehghan et al. showed that there was no relationship between blood sugar control and diabetes self-efficacy and the effective factor in controlling blood sugar was the duration of diabetes ${ }^{15}$. Similar results were obtained in the study by Beckerle et al. ${ }^{1}$ They showed that self-efficacy and self-care were not significantly correlated with blood sugar control and this result could be related to patients' treatment and medication regimens. Although patients measured their blood sugar levels and considered their ability to be at an acceptable level, if their medication levels were not appropriate, their blood sugar levels would not be properly controlled ${ }^{1}$. This was one of the limitations of the present study since the drug regimen has not been studied.

In contrast, the results of the present study are not consistent with the study by Van Allen et al., showing that changes in hope therapy affect both hemoglobin A1C levels and self-control of blood sugar positively ${ }^{16}$. In addition, Santos et al. have demonstrated that the high levels of hope are directly related to blood sugar control in the adolescents with diabetes ${ }^{17}$. This difference in results can be attributed to factors such as different measurement tools, as the present study was an interventional study investigating the self-efficacy of the adolescents in measuring blood sugar, whereas the abovementioned studies were descriptive studies evaluating the level of hemoglobin $\mathrm{A} 1 \mathrm{C}$ as the means of controlling blood sugar.
With regard to educational self-efficacy, it was found that hope therapy did not have a significant effect on this variable that is not consistent with previous studies. Tian et al. ${ }^{11}$ and Bayanfar et al. ${ }^{10}$ have shown that group hope therapy has a positive effect on educational self-efficacy. Feldman and Kubota also showed that hope has a positive relationship with educational achievement ${ }^{18}$. In explaining this finding, in addition to the differences in the age of the samples in the present study and the studies mentioned, it should be noted that in the present study, self-efficacy was examined in different areas and did not focus solely on educational self-efficacy. Moreover, the present study explored educational self-efficacy in the adolescents with diabetes, while the samples in the mentioned studies did not have any illness. Of course, differences in the number of samples and different cultures of countries can also cause this discrepancy.

Although this study tried to control confounding variables by random allocation of the participants to the intervention and control groups, individual differences in mood, nutrition, and family support may possibly have influenced the results of this study in some way. Receiving information from other sources such as the Internet and television or from the intervention group, familial stress, as well as the level of interest and cooperation of the samples, and the optimal and correct application of the learned methods were among the uncontrollable intervening variables in this study.

\section{CONCLUSIONS}

The results indicate that group hope therapy could be used as an effective method in increasing the self-efficacy of the adolescents with T1D. However, in the field of educational self-efficacy and self-efficacy in measuring blood sugar, it has not been effective. This inefficacy can be attributed to ways of adapting to the disease, changes in puberty, and also changes in the influence of parents and peers on the decision-making of adolescents.

\section{AUTHORS' CONTRIBUTIONS}

NNE: Conceptualization, Data curation, Formal Analysis, Resources, Writing - original draft, Writing - review \& editing. ST: Conceptualization, Data curation, Formal Analysis, Resources, Writing - original draft, Writing - review \& editing. SJM: Conceptualization, Data curation, Formal Analysis, Resources, Writing - original draft, Writing review \& editing. NM: Conceptualization, Data curation, Formal Analysis, Resources, Writing - original draft, Writing - review \& editing. 


\section{REFERENCES}

1. Datye KA, Moore DJ, Russell WE, Jaser SS. Association of self-efficacy and self-care with glycemic control in diabetes. Diabetes Spectr. 2013;26(3):172-8. https://doi.org/10.2337/ diaspect.26.3.172

2. Lawrence JM, Yi-Frazier JP, Black MH, Anderson A, Hood $K$, Imperatore $G$, et al. Demographic and clinical correlates of diabetes-related quality of life among youth with type 1 diabetes. J Pediatr. 2012;161(2):201-7.e2. https://doi. org/10.1016/j.jpeds.2012.01.016

3. Snyder CR. Handbook of hope: theory, measures, and applications. San Diego: Academic press; 2000.

4. Movahedi M, Kariminejad K, Babapour J, Movahedi Y. The effectiveness of hope therapy base on groups to increase the components of self-esteem and psychological health in depressed people. J Adv Med Biomed Res. 2015[cited on Jun. 6, 2015];23(98):132-44. Available from: https://zums. ac.ir/journal/article-1-3152-en.html\&sw=The+Effectiveness + of+Hope+Therapy+Base+on+Groups+To+Increase+the+C omponents+of+Self-Esteem+and+Psychological+Health+in +Depressed+People

5. Tahmasian C, Jazayeri AR, Mohammadkhani P, Ghazi-Tabatabaie M. Modeling of physical self-efficacy in adolescence depression: bandura's agentic model of depression. J. Rehabil. 2007[cited on Oct. 11, 2015];8:34-9. Available from: http://rehabilitationj. uswr.ac.ir/article-1-127-en.html

6. Haghayegh A, Ghasemi N, Neshardoost HT, Kajbaf MB, Khanbani M. Psychometric properties of diabetes management. Iran J Endocrinol Metab. 2010[cited on Jul. 15, 2010];12(2):111-5. Available from: http://ijem.sbmu.ac.ir/article-1-789-en.html

7. Moghtaderi M, Saffarinia M, Zare H, Alipour A. Effectiveness of the package of hope therapy based on positivist approach on the self-efficacy and loneliness of Parkinson patients. Quarterly Journal of Health Psychology. 2020;8(32):73-92. https://doi.org/10.30473/HPJ.2020.45983.4376

8. Azdin SM, Musavi SAM, Jalali M, Kakavand A. The effectiveness of mindfulness-based cognitive therapy on social self-efficacy and depression. Journal of Developmental Psychology. 2018[cited on May 6, 2018];14(55):305-14. Available from: http://jip.azad.ac.ir/article_541256.html?lang=en

9. Farnam A, Madadizade T. Effect of positive training on positive psychological states (character strengths) of female high school students. Positive Psychology Research. 2017;3(1):61-76. https://doi.org/10.22108/ppls.2017.96495.0
10. Bayanfar $F$. The effectiveness of group hope therapy based on Snyder approach on the beliefs of academic self-efficacy, academic vitality and psychological well-being of students. Journal of Educational Leadership and Administration. 2018[cited on Dec. 21, 2018];12(3):31-51. Available from: http://edu.journals.iau-garmsar.ac.ir/article_545807.html

11. Tian M, Yan S, Wang N. Evaluating the effectiveness of Snyder's theory-based group hope therapy to improve self-efficacy of university students in finance. Neuroquantology. 2018;16(6):11824. https://doi.org/10.14704/nq.2018.16.6.1314

12. Karimi S, Delavar A, Ghaemi F, Dortaj F. Effectiveness of Hope therapy on psychological capital of patients with type II diabetes mellitus. J Diabetes Nurs. 2019[cited on Jul. 6, 2019];7(2):809-19. Available from: http://jdn.zbmu.ac.ir/ article-1-362-en.html

13. Ghaedi TM, Shiroodi SG. The efficacy of group hope therapy on depression, loneliness, and self-efficacy in female students. J Child Ment Health. 2016[cited on Sept. 6, 2016];3(2):65-75. Available from: http://childmentalhealth. ir/article-1-138-en.html

14. Datye KA, Moore DJ, Russell WE, Jaser SS. A review of adolescent adherence in type 1 diabetes and the untapped potential of diabetes providers to improve outcomes. Curr Diab Rep. 2015;15(8):621. https://doi.org/10.1007/s11892015-0621-6

15. Dehghan H, Charkazi A, Kouchaki GM, Zadeh BP, Dehghan BA, Matlabi M, et al. General self-efficacy and diabetes management self-efficacy of diabetic patients referred to diabetes clinic of Aq Qala, North of Iran. J Diabetes Metab Disord. 2017;16:8. https://doi.org/10.1186/s40200-016-0285-z

16. Van Allen J, Steele RG, Nelson MB, Peugh J, Egan A, Clements $M$, et al. A longitudinal examination of hope and optimism and their role in type 1 diabetes in youths. J Pediatr Psychol. 2016;41(7): 741-9. https://doi.org/10.1093/jpepsy/jsv113

17. Santos FRM, Sigulem D, Areco KN, Gabbay MAL, Dib SA, Bernardo V. Hope matters to the glycemic control of adolescents and young adults with type 1 diabetes. J Health Psychol. 2015;20(5):681-9. https://doi.org/10.1177/1359105315573429

18. Feldman DB, Kubota M. Hope, self-efficacy, optimism, and academic achievement: Distinguishing constructs and levels of specificity in predicting college grade-point average. Learn Individ Differ. 2015;37:210-6. https://doi.org/10.1016/j. lindif.2014.11.022 